\title{
Biochemical and EEG Studies in Phenylketonuric Children during Phenylalanine Tolerance Tests
}

\author{
BARBARA E. CLAYTON, A. A. MONCRIEFF, G. PAMPIGLIONE, and JEAN SHEPHERD \\ From The Hospital for Sick Children, Great Ormond Street, London
}

The mechanisms by which neurological and mental disorders are produced in phenylketonuric children are not yet understood. The hypothesis that abnormal amounts of circulating metabolites might 'poison the brain' has been generally accepted and forms the basis of present-day dietary treatment.

It has been shown that the most satisfactory clinical improvement on a low phenylalanine diet occurs when the baby is treated very early in life (for a review see Woolf, 1961, and the Report to the Medical Research Council of the Conference on Phenylketonuria, 1963). The observation that the EEG of untreated phenylketonuric babies shows only minor abnormalities in the first 3 months of life with an increase in abnormal wave forms between 6 months and 1 year (Pampiglione, 1961) might suggest that the underlying process, whatever its nature, is not a static one. The relationship, however, between the severity of the clinical symptomatology, the blood level of phenylalanine, the type and severity of the EEG abnormality, and the developmental quotient in each phenylketonuric child is not a simple one. This relationship remains disconcertingly variable even in children stabilized on diets with either persistently low, or with considerably variable phenylalanine levels in their

Received August 12, 1965. blood (Coates, 1961; Pampiglione, 1961; Woolf, 1961; Tizard, 1962; Hudson, Dickinson, and Ireland, 1963; Bessman, 1964).

A low phenylalanine diet is unpalatable and involves much co-operation from both the mother and the patient. It seems, therefore, undesirable that the diet should be continued for longer than is necessary. No valid criteria, however, are yet known upon which to base a decision as to when to interrupt without any risks the dietary treatment. There are a few patients described in the literature (see Table I and Bickel and Grüter, 1963) in whom cessation of the diet did not lead to deterioration. Theoretically, however, some irreversible brain damage might follow a return to a normal diet even for a few months: the low phenylalanine diet, therefore, is continued for many years.

This paper describes an attempt to find some acceptable means to select phenylketonuric children with a view to adjusting their dietary requirements during prolonged treatment.

\section{Patients and Method}

Over the last 12 years 80 children with phenylketonuria have been followed up in this hospital by one of us (A.A.M.). Some of them, and several of their relatives, had a phenylalanine tolerance test as part

TABLE I

Reports of Phenylketonuric Patients in Whom the Diet Was Stopped

\begin{tabular}{|c|c|c|c|c|}
\hline Author & $\begin{array}{l}\text { Age When Diet } \\
\text { was Begun }\end{array}$ & $\begin{array}{c}\text { Age When } \\
\text { Diet was } \\
\text { Stopped (yr.) }\end{array}$ & $\begin{array}{c}\text { Subsequent } \\
\text { Period Off } \\
\text { Diet (yr.) }\end{array}$ & Comments on IQ \\
\hline $\begin{array}{l}\text { Horner, Streamer, Alejandrino, } \\
\text { Reed, and Ibbott (1962) } \\
\begin{array}{ll}\text { Murphy (1963) } & \ldots \\
\text { Vandeman (1963) } & \ldots\end{array} \\
\begin{array}{ll}\text { Koch, Fishler, Schild, and } \\
\text { Ragsdale (1964) }\end{array}\end{array}$ & $\begin{array}{l}\text { Neonatal period } \\
\text { Neonatal period } \\
\text { Neonatal period } \\
\text { Early infancy } \\
\text { Early infancy } \\
19 \text { weeks } \\
4 \text { weeks }\end{array}$ & $\begin{array}{c}4 \\
4 \\
4 \\
4 \cdot 2 \\
2 \cdot 8 \\
3 \\
3\end{array}$ & $\begin{array}{rl} & 2 \cdot 5 \\
1 \cdot 5 & 0 \cdot 17 \\
\simeq & 3 \\
\simeq & 3 \\
3 \cdot 5 \\
3 \cdot 5 \\
\\
2 \cdot 5\end{array}$ & $\begin{array}{l}\text { 90-95, maintained off diet } \\
70 \text {, maintained off diet } \\
\text { Low } 90 \text { s, maintained off diet } \\
85 \pm 5 \text {, maintained off diet } \\
90, \text { maintained off diet } \\
\text { At } 4 \cdot 8 \text { yr., } 67 \text {; at } 7 \cdot 3 \text { yr., } 74 \\
\text { At } 3.9 \text { yr., } 85 \text {; at } 6.5 \text { yr., } 94 \\
\text { 89, maintained off diet }\end{array}$ \\
\hline
\end{tabular}


TABLE II

Clinical Data on Patients Studied

\begin{tabular}{|c|c|c|c|c|c|c|c|c|}
\hline Subject & Sex & $\begin{array}{c}\text { Phe Level Before } \\
\text { Diet } \\
\text { (mg./100 ml. serum) }\end{array}$ & $\begin{array}{l}\text { Age When } \\
\text { Diet Began }\end{array}$ & $\begin{array}{l}\text { Dietary } \\
\text { Control* }\end{array}$ & $\begin{array}{c}\text { Period on Diet } \\
\text { Before Tolerance } \\
\text { Test }\end{array}$ & $\begin{array}{l}\text { Age at Time of } \\
\text { Tolerance Test }\end{array}$ & $\begin{array}{c}\text { IQ } \\
\text { Prior } \\
\text { to } \\
\text { Diet }\end{array}$ & $\begin{array}{c}\text { IQ Nearest } \\
\text { Time of } \\
\text { Tolerance } \\
\text { Test }\end{array}$ \\
\hline $\begin{array}{l}\text { J.P. } \\
\text { D.B. }\end{array}$ & F & $\begin{array}{l}25 \\
20\end{array}$ & $\begin{array}{l}16 \text { dy. } \\
5 \text { wk. }\end{array}$ & $\begin{array}{l}\text { Satisfactory } \\
\text { Fair }\end{array}$ & $\begin{array}{l}4 \frac{1}{2} \text { mth. } \\
3 \text { yr. } 8 \text { mth. }\end{array}$ & $\begin{array}{l}5 \text { mth. } \\
3 \text { yr. } 9 \text { mth. }\end{array}$ & $\begin{array}{r}108 \\
85\end{array}$ & $\begin{array}{c}98 \\
86(1 \mathrm{yr} . \\
\text { before } \\
\text { test) }\end{array}$ \\
\hline K.N. & $\mathbf{M}$ & 25 & 8 wk. & Satisfactory & $2 \mathrm{mth}$. & $4 \mathrm{mth}$. & 94 & $\begin{array}{l}103 \text { (at } 6 \\
\text { mth. of } \\
\text { age) }\end{array}$ \\
\hline $\begin{array}{l}\text { N.M. } \\
\text { L.L. } \\
\text { J.J. }\end{array}$ & $\begin{array}{l}\mathbf{M} \\
\mathbf{M}\end{array}$ & $\begin{array}{c}25 \\
20 \\
\text { Not known } \\
\text { Phenistix + ve }\end{array}$ & $\begin{array}{l}1 \text { yr. } 2 \text { wk. } \\
1 \text { yr. } 2 \text { mth. } \\
1 \text { yr. } 8 \text { mth. }\end{array}$ & $\begin{array}{c}\text { Satisfactory } \\
\text { Satisfactory } \\
\text { Fair }\end{array}$ & $\begin{array}{l}18 \mathrm{dy} . \\
1 \mathrm{mth} . \\
11 \mathrm{yr} .11 \mathrm{mth} .\end{array}$ & $\begin{array}{l}1 \text { yr. } 1 \mathrm{mth} . \\
1 \text { yr. } 3 \mathrm{mth} . \\
13 \text { yr. } 7 \mathrm{mth} \text {. }\end{array}$ & $\begin{array}{l}51 \\
58 \\
42\end{array}$ & $\frac{7}{59}$ \\
\hline D.P. & $\mathbf{F}$ & $\begin{array}{l}\text { Not known } \\
\text { Phenistix + ve }\end{array}$ & 1 yr. 10 mth. & Fair & 3 yr. 4 mth. & 5 yr. 2 mth. & 67 & 103 \\
\hline C.J. & $\mathbf{M}$ & $\begin{array}{l}\text { Not known } \\
\text { Phenistix }+ \text { ve }\end{array}$ & 2 yr. $3 \mathrm{mth}$. & Fair & 5 yr. 3 mth. & 7 yr. 6 mth. & 36 & 78 \\
\hline C.K. & $\mathbf{F}$ & $\begin{array}{l}\text { Not known } \\
\text { Phenistix + ve }\end{array}$ & $3 \mathrm{yr}$. & Poor & 6 yr. 5 mth. & 9 yr. 5 mth. & 71 & 82 \\
\hline $\begin{array}{l}\text { J.K. } \\
\text { M.W. }\end{array}$ & $\begin{array}{l}\mathbf{M} \\
\mathbf{M}\end{array}$ & $\begin{array}{c}20 \\
\text { Not known } \\
\text { Phenistix }+ \text { ve }\end{array}$ & $\begin{array}{l}3 \mathrm{yr} . \\
6 \mathrm{yr} .\end{array}$ & $\begin{array}{l}\text { Fair } \\
\text { Poor }\end{array}$ & $\begin{array}{l}2 \text { yr. } 9 \text { mth. } \\
5 \text { yr. } 11 \mathrm{mth} \text {. }\end{array}$ & $\begin{array}{l}5 \text { yr. } 9 \text { mth. } \\
11 \text { yr. } 11 \mathrm{mth} \text {. }\end{array}$ & $\begin{array}{l}70 \\
38\end{array}$ & $\begin{array}{r}100 \\
53\end{array}$ \\
\hline MaW. & $\mathbf{F}$ & $\begin{array}{l}\text { Not known } \\
\text { Phenistix + ve }\end{array}$ & 8 yr. 9 mth. & Poor & 6 yr. $5 \mathrm{mth}$. & 15 yr. 2 mth. & 49 & 45 \\
\hline
\end{tabular}

* Satisfactory $=$ majority of serum Phe levels under $4 \mathrm{mg} . / 100 \mathrm{ml}$.

Poor = majority of serum Phe levels over $4 \mathrm{mg} . / 100 \mathrm{ml}$.

Fair = periods when control has been satisfactory, and other periods when it has been poor.

of their special biochemical studies. From this group 12 children were selected for a concomitant EEG control during a phenylalanine tolerance test, the whole procedure lasting altogether between $4 \frac{1}{2}$ and $6 \frac{1}{2}$ hours. Details of the patients studied are shown in Table II. The age at which the dietary treatment had begun ranged from 16 days to $8 \frac{3}{4}$ years. The dietary control was satisfactory in some patients, but rather poor in others. The first 6 children in Table II were already in-patients in this hospital at the time of the test, while the other 6 , who had been previously in-patients, had been followed up from the out-patients department and were readmitted for the day of the test.

All the EEGs were taken with uniform technique either in the ward, at the patient's bedside, or in the department. The electrodes were silver-silver chloride discs stuck to the scalp with collodion according to measurements from bony landmarks (Pampiglione, 1956). Particular attention was devoted to the exploration of the anterior frontal regions and the posterior temporal regions, in view of our previous experience with phenylketonuric children of various age-groups. The amplification was usually 10 microvolts per millimetre pen deflection, but the gain on occasions had to be reduced considerably. The time constant employed throughout this series of tests was 0.3 second and most of the time no HF cut was used.

The apparatus was a portable 8 channel Offner
Type ' $T$ ' and the paper speed was either $15 \mathrm{~mm}$. or $30 \mathrm{~mm}$. per second. Recording started some half an hour before the phenylalanine load, even in those children who had had several EEG tests on previous occasions. Recording was continuous for the first hour after the phenylalanine load and then somewhat intermittent over the following 3- to 5-hour period.

Serum phenylalanine was estimated by a paper chromatographic method based on that of Berry (1957). The main modifications included (a) the use of Whatman paper No. $3 \mathrm{HR}$, since Hanes (1961) showed that this gave a lower ninhydrin blank value and better resolution of amino acids; (b) the chromatogram was run overnight in a butanol: acetic acid: water mixture (4:1 : $1 \cdot 7$ by vol.); (c) the colour was developed by a cadmium-ninhydrin reagent (Atfield and Morris, 1961), eluted with methyl alcohol, and read at 500 millimicron. The average percentage recovery when 5 to $20 \mathrm{mg}$. of phenylalanine were added to $100 \mathrm{ml}$. of serum and the whole procedure carried out, was $87 \pm 4$ (standard deviation).

L-phenylalanine (Light \& Co. Ltd.) was given in a dosage of $0.1 \mathrm{~g} . / \mathrm{kg}$. body weight to the fasting patient, mixed with a few $\mathrm{ml}$. of orange or black currant juice. Immediately afterwards the child was given a glass of orange or black currant juice mixed with $10 \mathrm{~g}$. glucose.

Finger-prick samples of blood were taken for 
TABLE III

Blood Sugars During Tolerance Tests

\begin{tabular}{|c|c|c|c|c|c|c|}
\hline \multirow{2}{*}{ Subject } & \multicolumn{6}{|c|}{ Blood Sugar (mg./100 ml.) } \\
\hline & Fasting & 40 minutes & 60 minutes & 2 hours & 4 hours & 6 hours \\
\hline $\begin{array}{l}\text { J.P. } \\
\text { D.B. } \\
\text { K.N. } \\
\text { H.M. } \\
\text { L.L. } \\
\text { J.J. } \\
\text { D.P. } \\
\text { C.J. } \\
\text { C.K. } \\
\text { J.K. } \\
\text { M.W. } \\
\text { Ma.W. }\end{array}$ & $\begin{array}{r}89 \\
76 \\
86 \\
83 \\
71 \\
86 \\
= \\
= \\
110 \\
78 \\
70\end{array}$ & $\begin{array}{r}102 \\
132 \\
118 \\
89 \\
75 \\
83 \\
176 \\
130 \\
105 \\
87 \\
118\end{array}$ & $\begin{array}{r}102 \\
104 \\
85 \\
72 \\
100 \\
70 \\
120 \\
91 \\
107 \\
70 \\
96\end{array}$ & $\begin{array}{r}123 \\
82 \\
70 \\
66 \\
77 \\
83 \\
139 \\
87 \\
100 \\
83 \\
80\end{array}$ & $\begin{array}{r}76 \\
100 \\
96 \\
73 \\
125 \\
93 \\
85 \\
125 \\
79 \\
104 \\
66 \\
78\end{array}$ & $\begin{array}{l}70 \\
95\end{array}$ \\
\hline
\end{tabular}

A dash (-) indicates that sugar was not estimated.

serum phenylalanine estimations during the fasting period before the load, and at intervals up to 4 or 6 hours after the load.

Since the possible occurrence of hypoglycaemia would have complicated the interpretation of the EEG findings, all patients (except D.P.) were given drinks of fruit juice containing $10 \mathrm{~g}$. glucose at 2-hourly intervals throughout the investigation. Blood sugars were estimated by a modification of Folin and Wu's method (Wilkinson, 1960), on many of the samples removed for phenylalanine determinations. The results, given in Table III, indicated that no periods of marked hypoglycaemia occurred in any of the children in this series.

The test was performed twice in L.L. and D.P. in whom pyridoxine had been administered some days before the second load in connexion with another investigation. In addition to the usual investigations, Ma.W. and M.W. on separate days also had EEG studies and phenylalanine estimations for 4 hours without a phenylalanine load being given, but with regular glucose drinks.

\section{Results and Discussion}

The evaluation of the type and severity of the EEG alterations following the phenylalanine load was complicated by several factors, such as: (1) the different ages of the 12 children tested; (2) the individual differences in the type and severity of the EEG abnormality observed before the administration of the load; (3) the possible occurrence of diurnal variations in the EEG patterns, irrespective of the administration of a phenylalanine load; (4) the occurrence of drowsiness or sleep during a test that lasts several hours, irrespective of the administration of the load; (5) the occasional occurrence of clinically recognizable seizures in a considerable proportion of children with phenylketonuria; and (6) the presence, particularly in the older children, of considerable asymmetries between the activities of the two hemispheres which might independently vary during the test.

Rather than embark on a lengthy description of the various EEG features seen in each child, the patterns observed on the same morning, before the phenylalanine load, were taken as a baseline. An arbitrary grading was then given to the degree of changes, if any, occurring about half an hour, 1 hour, 2 hours, 4 hours, and 6 hours following the phenylalanine load, as compared with the baseline features in each child. The results are shown in Table IV and an example is illustrated in the Figure.

Since Hsia, Driscoll, Troll, and Knox (1956) first detected heterozygotes for phenylketonuria by means of phenylalanine tolerance tests, a number of workers have confirmed and extended their work. Few data are available on tolerance tests in patients with phenylketonuria. Tischler and McGeer (1962) administered phenylalanine to 4 untreated patients aged 8 to 12 years; the fasting values for serum phenylalanine were 28 to $33.6 \mathrm{mg}$. $/ 100 \mathrm{ml}$. and increases of 13 to $17 \mathrm{mg}$. occurred with the loads. Woolf, Ounsted, Lee, Humphrey, Cheshire, and Steed (1961) mention that a loading dose of phenylalanine altered the EEG pattern strikingly in one patient but do not mention details of their technique.

In our material the fasting values for serum phenylalanine showed a great deal of individual variations, possibly because not all the patients were dietetically well controlled. Following the phenylalanine load, the levels rose in all our patients (see Table V), but the rate of rise and the peak values reached varied a great deal from one patient to the other. In the 2 children in whom the test was 
TABLE IV

EEG Change After Load

\begin{tabular}{|c|c|c|c|c|c|c|}
\hline Subject & $\frac{1}{2}$ hour & 1 hour & 2 hours & 4 hours & 6 hours & Comments \\
\hline J.P. & ?0 'Jumps' & ?० 'Jumps' & 0 & ?0 'Jumps' & & Difficult case; probably little if any \\
\hline D.B. & $?+$ Asleep & 0 & 0 & 0 Asleep & 0 & $\begin{array}{l}\text { Change } \\
\text { Except for early sleep period little }\end{array}$ \\
\hline $\begin{array}{l}\text { K.N. } \\
\text { M.H. }\end{array}$ & $\begin{array}{c}\text { 0 Asleep } \\
++ \text { Seizure }\end{array}$ & $\begin{array}{l}0 \text { Asym. } \\
++\end{array}$ & $\begin{array}{l}0 \\
+\end{array}$ & $\begin{array}{l}\mathbf{0} \\
+\end{array}$ & & $\begin{array}{l}\text { if any over-all change } \\
\text { Little if any change, in spite of sleep } \\
\text { Marked early change and seizure, }\end{array}$ \\
\hline L.L. I & $\begin{array}{l}+ \\
+\end{array}$ & $\begin{array}{l}+ \text { Asleep } \\
+ \text { Asleep }\end{array}$ & $\begin{array}{l}++ \\
++\end{array}$ & + & & $\begin{array}{l}\text { also later changes } \\
\text { Definite change in both tests }\end{array}$ \\
\hline $\begin{array}{l}\text { D.J. I } \\
\text { C.J. } \\
\text { II }\end{array}$ & $\begin{array}{c}\text { Asym. } \\
0 \\
0 \\
+\end{array}$ & $\begin{array}{l}++ \\
0 \\
0 \\
+\end{array}$ & $\begin{array}{c}++ \\
+0 \\
+\stackrel{+}{\text { ? }} \\
+\mathrm{R}>\mathrm{L}\end{array}$ & $\begin{array}{c}+\underset{? 0}{+}+ \\
+\stackrel{?}{\mathrm{R}} \\
+\mathrm{R}>\mathrm{L}\end{array}$ & +++ & $\begin{array}{l}\text { Definite prolonged change } \\
\text { Little if any change after } 2 \text { hours } \\
\text { in both tests } \\
\text { Marked change with increase in }\end{array}$ \\
\hline C.K. & + & + & + & ++ & & $\begin{array}{l}\text { local abnormality } \\
\text { Definite change, particularly after }\end{array}$ \\
\hline $\begin{array}{l}\text { J.K. } \\
\text { M.W.W. } \\
\text { Ma.W. }\end{array}$ & $\begin{array}{c}\text { ? } \\
+ \text { Asleep } \\
+ \text { Drowsy }\end{array}$ & $\begin{array}{l}0 \\
+\underset{+}{\text { Drowsy }} \\
+\end{array}$ & $\begin{array}{l}0 \\
+ \\
++\end{array}$ & $\begin{array}{l}0 \text { Asleep } \\
++ \\
++\end{array}$ & $? 0$ & $\begin{array}{l}\text { Little if any change } \\
\text { Definite prolonged change } \\
\text { Definite prolonged change }\end{array}$ \\
\hline
\end{tabular}

$0=$ no change; $? 0=$ doubtful change $+=$ moderate but definite change $;++=$ marked change; $+++=$ severe change

repeated after an interval of a few weeks (L.L. and D.P.) the detailed shape of the tolerance curve was not identical to that of the first test in either case. Pyridoxine, however, had been given to both children in the period between the 2 tests and this might have influenced the second tolerance curves. From the EEG aspects, however, the child L.L., who had shown a considerable EEG change during the first phenylalanine load, showed a similar EEG change during the second load, although the absolute phenylalanine values in the serum were not identical. The other child (D.P.) showed only a doubtful EEG change on both occasions, although the absolute values of phenylalanine in her serum were grossly different during the 2 tests.

The 2 children (M.W. and Ma.W.), who had a prolonged EEG study during a control period without administration of the phenylalanine load, showed only a minimal, if any, EEG change over a 4-hour period, and during this period no significant changes occurred in the blood phenylalanine levels. The same 2 children, however, showed a definite deterioration in the EEG features over a similar period of time after the phenylalanine load. The blood phenylalanine curves during the tolerance test, however (see Table V), were not similar in these two children. This would suggest that following a phenylalanine load the factors that determine marked alterations in an already abnormal EEG are not directly related to the changes in the serum phenylalanine levels but rather to a chain of, as yet, unknown events. With the exclusion of the paper by Woolf (1961) there seems to have been little work done to establish a combined biochemical and EEG tolerance test to a phenylalanine load in phenylketonuric children. It is, therefore, difficult

TABLE V

Phenylalanine Levels Before and After Loading

\begin{tabular}{|c|c|c|c|c|c|c|}
\hline \multirow{2}{*}{ Subject } & \multicolumn{6}{|c|}{ Serum Phenylalanine (mg./100 ml.) } \\
\hline & Fasting & 40 minutes & 60 minutes & 2 hours & 4 hours & 6 hours \\
\hline $\begin{array}{l}\text { J.P. } \\
\text { D.B. } \\
\text { K.N. } \\
\text { H.M. } \\
\text { L.L. } \\
\text { J.J. } \\
\text { D.P. } \\
\text { C.J. } \\
\text { C.K. } \\
\text { J.K. } \\
\text { M.W. } \\
\text { Ma.W. }\end{array}$ & $\begin{array}{r}8 \cdot 8 \\
4 \cdot 3 \\
2 \cdot 5 \\
4 \cdot 5 \\
6 \cdot 3 \\
\star 6 \cdot 2 \\
3 \cdot 1 \\
9 \cdot 0 \\
\star 2 \cdot 3 \\
9 \cdot 4 \\
2 \cdot 4 \\
15 \cdot 6 \\
9 \cdot 0 \\
12 \cdot 0\end{array}$ & $\begin{array}{r}13 \cdot 8 \\
18 \cdot 6 \\
6.2 \\
12.6 \\
11.6 \\
14.0 \\
8 \cdot 0 \\
15.3 \\
9.9 \\
10 \cdot 6 \\
6 \cdot 5 \\
19.5 \\
10.8 \\
17.6\end{array}$ & $\begin{array}{r}15 \cdot 6 \\
19 \cdot 0 \\
8.0 \\
12 \cdot 0 \\
20.5 \\
9.0 \\
23 \cdot 6 \\
11 \cdot 1 \\
10 \cdot 6 \\
6.4 \\
13.8 \\
10.4 \\
18.6\end{array}$ & $\begin{array}{r}15 \cdot 6 \\
20 \cdot 7 \\
10 \cdot 8 \\
17 \cdot 4 \\
15 \cdot 1 \\
22 \cdot 1 \\
13 \cdot 4 \\
26 \cdot 8 \\
11 \cdot 9 \\
18 \cdot 6 \\
8 \cdot 8 \\
15 \cdot 8 \\
12 \cdot 0\end{array}$ & $\begin{array}{r}20 \cdot 4 \\
19 \cdot 0 \\
19 \cdot 2 \\
21 \cdot 2 \\
19 \cdot 4 \\
21 \cdot 5 \\
9 \cdot 8 \\
24 \cdot 6 \\
14 \cdot 5 \\
21 \cdot 2 \\
12 \cdot 3 \\
26 \cdot 6 \\
10 \cdot 8\end{array}$ & $15 \cdot 7$ \\
\hline
\end{tabular}

* Loading repeated after the administration of pyridoxine. 
(a)

11.45 Ph 3.1
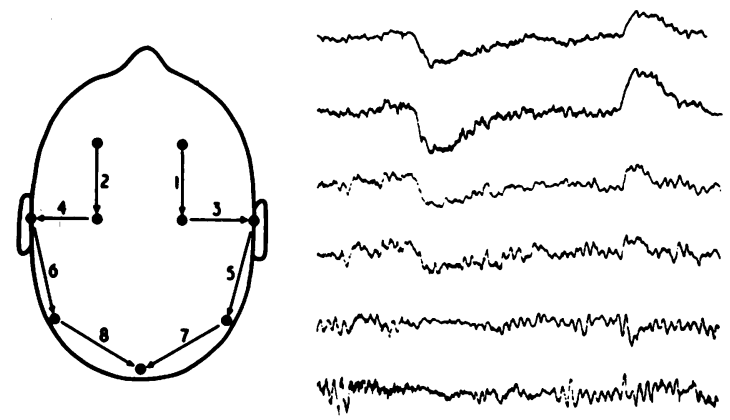

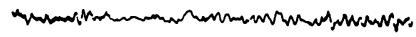

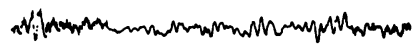

(b)

12.51 Ph.9

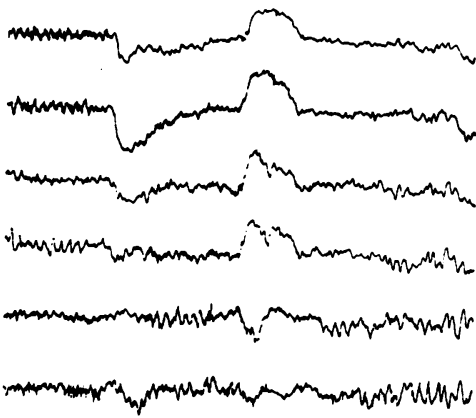

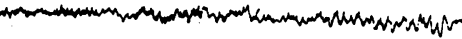

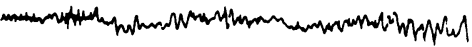

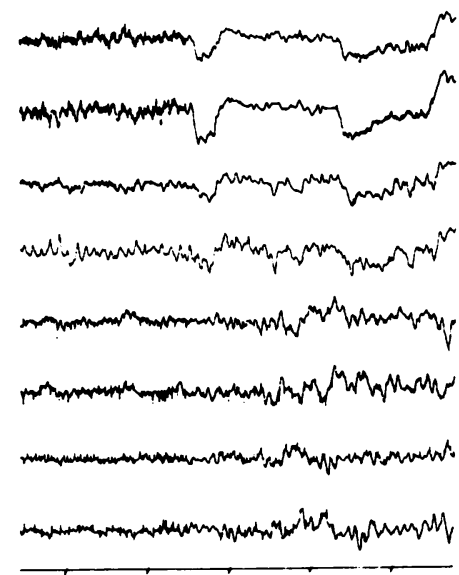

(c)

$$
\text { 等 }
$$

(d)

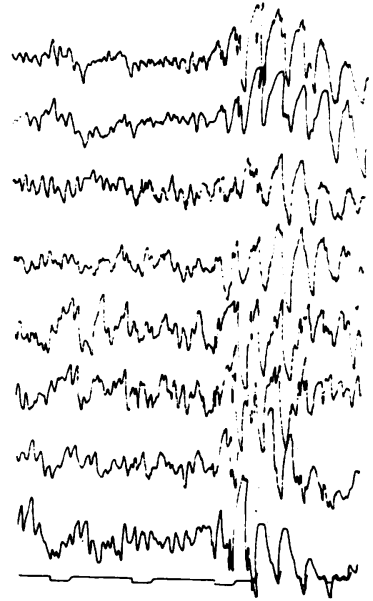

(e)

Fig. 1.-Case J.J., at the age of 13 years and 7 months. The phenylalanine load was given at 11.50 a.m. on September 7, 1964 (EEG No. 15195). (a) 11.45 a.m., serum phenylalanine (SPh) 3.1; (b) 12.51, SPh 9; (c) 13.48, SPh 13.4; (d) 15.48; SPh 9.8; (e) 18.11, SPh 15.7.

to compare our data with those of other workers.

Some behavioural changes occurred in some of our children during the prolonged test, but not in others. It is difficult to evaluate the significance of some of these changes. For example, sleep or drowsiness occurred in 6 out of the 12 children within the first hour of the test, apparently irrespective of the serum phenylalanine levels reached at the time. No gross mood changes were seen in any child, though most of them resented the repeated finger-pricking for blood sampling.

One baby (J.P.) believed to be clinically normal, had a few minimal 'jerks' on the day of the test, but these had already been observed before the administration of the phenylalanine load, were seen only during sleep, and might have passed unnoticed if it had not been for the prolonged EEG testing. Another child (H.M.) showed a marked EEG change 
and then a short-lived seizure less than half an hour after the administration of the load. However, other children in this series, already known to have had fits in the past, did not have any seizure at the time of the test, though the rise in their serum phenylalanine was considerable. There was, therefore, no evidence from both the present and other series of cases that the phenylalanine tolerance test in phenylketonuric children might be considered as a dangerous procedure. To avoid other complicating factors, the EEG tests were not accompanied by photic stimulation or hyperventilation or other manœuvres that might facilitate the occurrence of seizures.

The apparent lack of direct correlations between the degree of the increase in phenylalanine level in the blood and the presence or absence of EEG changes following the phenylalanine load is not understood. Experiments on animals, as described by Waisman, Wang, Palmer, and Harlow (1962) and Himwich (1964) are of considerable interest. However, since the rate of brain maturation in monkeys, dogs, and rats is so very different from that of children, the results of animal experiments would have to be accepted with some reserve.

The present findings do not offer a simple answer to the problem of the total duration of dietary treatment in phenylketonuric children. In fact, we do not know whether treatment with a diet low in phenylalanine, even if started early in life, should be continued until the child is 3,4 , or more years old, or whether the diet should continue for ever. From the biochemical aspects the tolerance curve in response to a phenylalanine load is abnormal in untreated phenylketonuric children as well as in most heterozygous 'carriers'. Such a curve is also abnormal with a variable and prolonged rise in phenylketonuric children apparently well controlled on diet. The fact that a considerable increase in EEG abnormality occurred in 7 of our 12 children after a phenylalanine load, suggests that in those 7 children a return to a normal diet should not be encouraged, at least until we know much more about the complex metabolic peculiarities of these children. It was interesting to notice in this small group of cases that the 5 children who showed only mild or negligible EEG changes during the phenylalanine tolerance test were those whose IQs near the time of the test were around normal. In 3 of these 5 children the dietary treatment had started in the first 2 months of life. In the other 2 (D.P. and J.K.), although the diet started at nearly 2 and 3 years respectively, a remarkable improvement had occurred in their IQs.

We are grateful to all the technicians who took part in this investigation. We are indebted to Dr. N. Raine and Miss D. McCubbing, B.Sc., for their help in the development of the method for the estimation of phenylalanine, to the Medical Research Council for the EEG apparatus, and to the Joint Research Board of The Hospital for Sick Children and the Institute of Child Health for financial support.

\section{REFERENCES}

Atfield, G. N., and Morris, C. J. O. R. (1961). Analytical separations by high-voltage electrophoresis: amino acids in protein hydrolysates. Biochem. F., 81, 606.

Berry, H. K. (1957). Paper chromatographic method for estimation of phenylalanine. Proc. Soc. exp. Biol. (N.Y.), 95, 71.

Bessman, S. P.(1964). Some biochemical lessons to be learned from phenylketonuria. F. Pediat., 64, 828 .

Bickel, H., and Grüter, W. (1963). Management of phenylketonuria. In Phenylketonuria, ed. F. L. Lyman, pp. 157-162. Charles C. Thomas, Springfield, Illinois.

Coates, S. (1961). Results of treatment in phenylketonuria. Brit. med. F., 1, 767.

Hanes, C. S. (1961). Quantitative chromatographic methods. Part 2. An approach to paper chromatography of improved resolving power and reproducibility. Canad. F. Biochem., 39, 119.

Himwich, W. (1964). Experimental phenylketonuria in puppies. Personal communication to be published.

Horner, F. A., Streamer, C. W., Alejandrino, L. L., Reed, L. H., and Ibbott, F. (1962). Termination of dietary treatment of phenylketonuria. New Engl. F. Med., 266, 79.

Hsia, D. Y.-Y., Driscoll, K. W., Troll, W., and Knox, W. E. (1956). Detection by phenylalanine tolerance tests of heterozygous carriers of phenylketonuria. Nature (Lond.), 178, 1239.

Hudson, F. P., Dickinson, R. A., and Ireland, J. T. (1963). Experiences in the detection and treatment of phenylketonuria. Pediatrics, 31, 47.

Koch, R., Fishler, K., Schild, S., and Ragsdale, N. (1964). Clinical aspects of phenylketonuria. Ment. Retard., 2, 47.

Murphy, D. (1963). Termination of dietary treatment of phenylketonuria. Irish f. med. Sci., 355.

Pampiglione, G. (1956). Anatomical considerations and electrode placement in routine EEG. Proc. electrophysiol. Technol. Ass., $7,1,20$.

- (1961). EEG studies in some inborn errors of metabolism. Acta VII int. Neurol. Cong., Rome, vol. 1, p. 53.

Report to the Medical Research Council of the Conference on Phenylketonuria (1963). Brit. med. F., 1, 1691.

Tischler, B., and McGeer, E. G. (1962). Effects of folic acid on the phenylalanine tolerance test in phenylketonuria. Canad. med. Ass. F., 87, 1331.

Tizard, J. (1962). The treatment of the mentally subnormal. In Aspects of Psychiatric Research, ed. D. Richter et al. Oxford University Press, London.

Vandeman, P. R. (1963). Termination of dietary treatment for phenylketonuria. Amer. F. Dis. Child., 106, 492.

Waisman, H. A., Wang, H., Palmer, G., and Harlow, H. F. (1962) Experimental phenylketonuria in infant monkeys: Proc. London Conference on the Scientific Study of Mental Deficiency, 1960, vol. 1, pp. 126-141.

Wilkinson, R. H. (1960). Chemical Micromethods in Clinical Medicine. C. C. Thomas, Springfield, Illinois.

Woolf, L. I. (1961). Nutrition in relation to phenylketonuria. Proc. Nutr. Soc., 21, 21.

- Ounsted, C., Lee, D., Humphrey, M., Cheshire, N. M., and Steed, G. R. (1961). Atypical phenylketonuria in sisters with normal offspring. Lancet, 2, 464. 